\title{
An investigation of resistance to $\beta$-lactam antimicrobials among staphylococci isolated from pigs with exudative epidermitis
}

\author{
Jeonghwa Park 1*, Robert M Friendship ${ }^{1}$, J Scott Weese ${ }^{2}$, Zvonimir Poljak ${ }^{1}$ and Cate E Dewey ${ }^{1}$
}

\begin{abstract}
Background: A high proportion of staphylococci isolated from pigs affected with exudative epidermitis were found to be resistant to $\beta$-lactam antimicrobials. The primary objective of this research was to investigate and characterize $\beta$-lactam resistance in Staphylococcus hyicus, Staphylococcus aureus and other staphylococci isolated from these pigs.

Results: The antimicrobial resistance patterns of 240 staphylococci isolates were determined by disk diffusion, of which 176 (73.3\%) of the isolates were resistant to $3 \beta$-lactams (penicillin G, ampicillin, and ceftiofur). The presence of mecA gene was identified in 63 staphylococci isolates from skin samples by PCR. The mecA gene was identified in $19 \mathrm{~S}$. aureus, 31 S. hyicus, 9 Staphylococcus chromogenes, 2 Staphylococcus pseudintermedius isolates, and in 1 isolate each of Staphylococcus arlettae, and Staphylococcus cohnii subspecies urealyticus. From SCCmec typing results, the majority $(45 / 63,71.4 \%)$ were shown to be SCCmec type V. One isolate was SCCmec III. Fourteen isolates were detected as mec class A, mec class C or ccr type 5. The ccr complex and mec complex was not detected in 3 isolates of methicillin resistant S. hyicus (MRSH) based on multiplex PCR. Of the 30 isolates of MRSA identified from nasal samples of the pigs, 29 isolates were SCCmec type V and 1 isolate was SCCmec type II. Staphyloccoci isolates that were mecA negative but resistant to $\beta$-lactam antimicrobials were further examined by screening for $\mathrm{mec} C$, however all were negative. Furthermore, the majority of mecA negative $\beta$-lactam resistant staphylococci isolates were susceptible to oxacillin and amoxicillin-clavulanic acid in a double disk diffusion test.

Conclusions: Methicillin resistance can be identified in a variety of staphylococcal species isolated from pigs. In this study there was a great deal of similarity in the SCCmec types between staphylococcal species, suggesting that resistance may be passed from one species of staphylococci to another species of staphylococci. While this has been reported for acquisition of methicillin-resistance from coagulase negative staphylococci to $S$. aureus, these data suggest that transmission to or from the porcine pathogen S. hyicus may also occur. The identification of methicillin resistance in a variety of staphylococcal species in pigs does raise concerns about the spread of serious multi-drug resistance in food producing animals and warrants further study.
\end{abstract}

Keywords: $\beta$-lactam resistance, Methicillin resistant Staphylococcus aureus, Methicillin-resistant Staphylococcus hyicus, Exudative epidermitis, Pigs, mecA gene, mecC (novel mecALGA251), SCCmec type V

\section{Background}

Exudative epidermitis occurs as a generalized or localized skin disease of young pigs. The disease is common, can result in high morbidity and if severe can cause high death losses [1]. Resistance to $\beta$-lactam antimicrobials among staphylococci isolated from pigs is common [2-5],

\footnotetext{
* Correspondence: piggyvet2011@gmail.com

${ }^{1}$ Department of Population Medicine, Ontario Veterinary College, University

of Guelph, 50 Stone Road, Guelph N1G2W1, ON, Canada

Full list of author information is available at the end of the article
}

but few studies have been conducted to examine this topic, apart from relatively recent studies that have evaluated the prevalence of methicillin-resistant Staphylococcus aureus (MRSA) colonization in healthy pigs. Public health concerns associated with MRSA in pigs have generated a great deal of interest, and numerous studies have documented the widespread prevalence of MRSA among the world pig population [6-9]. However, S. aureus has only minor significance as a swine pathogen, whereas other staphylococci such as Staphylococcus hyicus can result in economically

\section{Biomed Central}


important disease such as exudative epidermitis [10,11]. Previous studies by our group have identified that treatment failure in cases of exudative epidermitis in pigs is common, partly due to the widespread presence of multidrug resistance in staphylococci [5]. Resistance against the $\beta$-lactam family of antibiotics including penicillin $G$, ampicillin and cephalosporins was particularly noteworthy because penicillin is typically the drug of choice in the treatment of exudative epidermitis, almost exclusively in the absence of culture and susceptibility testing [5].

Acquired resistance to $\beta$-lactams is mediated through two main mechanisms, $\beta$-lactamase production or altered penicillin binding protein (PBP2a) production. Bacterial $\beta$-lactamases hydrolyze the $\beta$-lactam ring and in staphylococci typically confer resistance to penicillins (including amoxicillin and ampicillin). Inhibitors of $\beta$-lactamase (clavulanate, sulbactam, and tazobactam) can inhibit this resistance mechanism and $\beta$-lactam/ $\beta$-lactamase inhibitor combinations are widely used in some species, but not in the swine industry [12]. In contrast, altered PBP2a production encoded by mecA, results in low affinity for all $\beta$-lactams and confers broad resistance to $\beta$-lactams (including cephalosporins and carbapenems) that is not affected by $\beta$-lactamase inhibitors.

Despite the importance of S. hyicus in swine disease, the commonness of $\beta$-lactam use to treat staphylococcal infections, and clinical evidence indicating poor response of exudative epidermitis to $\beta$-lactams in some situations [5], there has been minimal investigation of $\beta$-lactam antimicrobial resistance in this species. The primary objective of this research was to investigate and characterize $\beta$-lactam resistance in S. hyicus, S. aureus and other staphylococci isolated from pigs affected with exudative epidermitis.

\section{Methods}

\section{Source of staphylococci isolates}

Staphylococcal isolates were obtained from a previous trial [5]. Briefly, researchers visited 30 farms with endemic exudative epidermitis, taking skin and nasal swabs of pigs (6 pigs per farm on average) with clinical signs of exudative epidermitis. One hundred and forty-four $S$. hyicus and 96 S. aureus isolates from skin samples were identified by the Animal Health Laboratory (AHL), University of Guelph, Ontario with standard laboratory techniques including colony morphology, haemolysis, Gram stain, catalase reaction and coagulase reaction. Antimicrobial susceptibility testing for penicillin G (10 units), ampicillin $(10 \mu \mathrm{g})$ and ceftiofur $(30 \mu \mathrm{g})$ were performed by disk diffusion (Kirby-Bauer procedure) as per Clinical and Laboratory Standard Institution (CLSI) guidelines [13] by AHL. There were 71.5\% (103/144) of $S$. hyicus isolates and 76\% (73/96) of S. aureus isolates concurrently resistant to penicillin G, ampicillin and ceftiofur.
Additionally, 30 MRSA isolates were recovered from nasal swabs. Nasal swabs were placed in enrichment broth and incubated for a day and then inoculated onto MRSA chromogenic agar (BBL CHROM agar MRSA, Becton Dickinson, SparksMD) and incubated aerobically for 24-48 h. Isolates were identified as $S$. aureus by Gram stain, catalase test, tube coagulase test and the $S$. aureus latex agglutination assay (Pastorex Staph plus, Bio Rad Laboratories Ltd, Mississauga, ON). Staphylococcal isolates that were resistant to penicillin G, ampicillin, or ceftiofur from skin samples and MRSA from nasal swabs were included in this study.

\section{Staphylococcus speciation}

Methicillin-resistant staphylococci that were presumed to be $S$. hyicus based on standard phenotypic identification were confirmed by S. hyicus PCR [14], sodA sequencing, or matrix assisted laser desorption/ionization - time of flight (MALDI-TOF) MS analysis by a Micro flex LT mass spectrometer (Bruker Daltonik) using the MALDI Biotyper software package with the reference database v.2.0 by AHL.

\section{Methicillin resistance}

Methicillin-resistance was evaluated by mecA PCR or detection of PBP2a by latex agglutination test (LAT) (Oxoid, Hants, UK). Amplification of mecA DNA with the primers 5'-GTT GTA GTT GTC GGG TTT GG-3' and 5'CTT CCA CAT ACC ATC TTC TTT AAC-3, using previously described conditions [15] was performed. Isolates that were $m e c A$-negative but resistant to ceftiofur were also tested for the novel $m e c$ homologue $m e c C$ using a multiplex PCR [16]. The primers for $m e c C$ were 5'-GAA AAA AAG GCT TAG AAC GCC TC- 3' and 5'-GAA GAT CTT TTC CGT TTT CAG C-3'. All amplifications were performed on supernatants from crude DNA extracts which were prepared and purified with InstaGene ${ }^{\mathrm{Tm}}$ Matrix (Bio-Rad Laboratories, Hercules, Canada). Products of PCR were electrophoresed through 1.5\% agarose gels and visualized through GelRed nucleic acid stain (BIOTIUM, Hayward, CA, USA).

\section{spa typing}

Thirty-nine MRSA isolates of 49 total MRSA isolates were selected to type the staphylococcal protein A gene (spa typing) [17].

\section{SCCmec typing}

All methicillin-resistant isolates were further characterized based on SCCmec elements using multiplex PCRs (M-PCRs) for typing of the mec complex class A and B, and the $c c r$ complex type 1 , type 2 , and type 3 (M-PCR 1 ), for typing of $c c r$ complex type 5 (M-PCR 2), for typing the mec complex class C (M-PCR 3), and for typing the ccr complex type 4 (M-PCR 4). The primer pairs used 
for M-PCR 1 and M-PCR 2 were referred from Zhang et al. [18] and the primer pairs used for M-PCR 3 and M-PCR 4 were referred from Kondo et al. [19].

\section{Effect of $\beta$-lactamase inhibitors}

Staphylococcal skin isolates that were resistant to penicillin G, ampicillin and ceftiofur but mecA gene negative were tested for susceptibility to oxacillin and amoxicillin/ clavulanic acid by disk diffusion [13]. Synergy between oxacillin and amoxicillin/clavulanic acid was detected by a double-disk diffusion test where a disk of amoxicillin/ clavulanic acid (20ug/10ug, respectively) and a disk of oxacillin (1ug) were placed $15 \mathrm{~mm}$ apart (center to center) on an inoculated agar plate. A clear extension of the edge of the oxacillin inhibition zone toward the disk containing clavulanic acid was interpreted as synergy, indicating the presence of a $\beta$-lactamase [20].

\section{Results}

A flow chart describing the testing and the results is presented in Figure 1. One hundred forty-four presumed S. hyicus and $96 \mathrm{~S}$. aureus isolates from skin swabs were further tested. The mecA was identified in $19 \mathrm{~S}$. aureus skin isolates and 44 presumed S. hyicus skin isolates. Thirty-one (70.5\%) of the presumptive $S$. hyicus isolates were reconfirmed as $S$. hyicus (MRSH), 9 were methicillin- resistant S. chromogenes (MRSC), 2 were methicillinresistant $S$. pseudintermedius (MRSP) and one each of $S$. arlettae and S. cohnii subsp. urealyticus. The thirty nasal isolates had been previously confirmed as MRSA. The characteristics of these methicillin-resistant staphylococci isolates are overviewed in Table 1.

The overall prevalence of methicillin resistance on farms was found to be $50 \%(15 / 30), 20 \%(6 / 30)$, and $26.7 \%(8 / 30)$ for MRSH, MRSA (skin samples), and MRSA (nasal samples), respectively. Twenty farms out of 30 farms had methicillin-resistant staphylococci from either the skin or nasal samples. Five farms had pigs harbouring both MRSA (skin and nose samples) and MRSH, and 5 farms had pigs harbouring both MRSA (skin and nasal samples) and methicillin- resistant non- S. aureus staphylococci (excluding MRSH). Seven spa types were detected from 39 MRSA isolates. The spa type t034 (539), a common ST398 strain, was predominant (84.6\%). The ST398associated t571 and t011 were found in single pigs and spa types t002, t026, t8588 and t1298 were also found once each.

The majority of SCCmec types in methicillin-resistant staphylococci in the study were SCCmec type V (75.3\%) (Table 2), with SCCmec type V accounting for $97.6 \%$ of MRSA (48/49) and 61.3\% of MRSH (19/31) isolates. Seventeen isolates only yielded results for mec gene complex

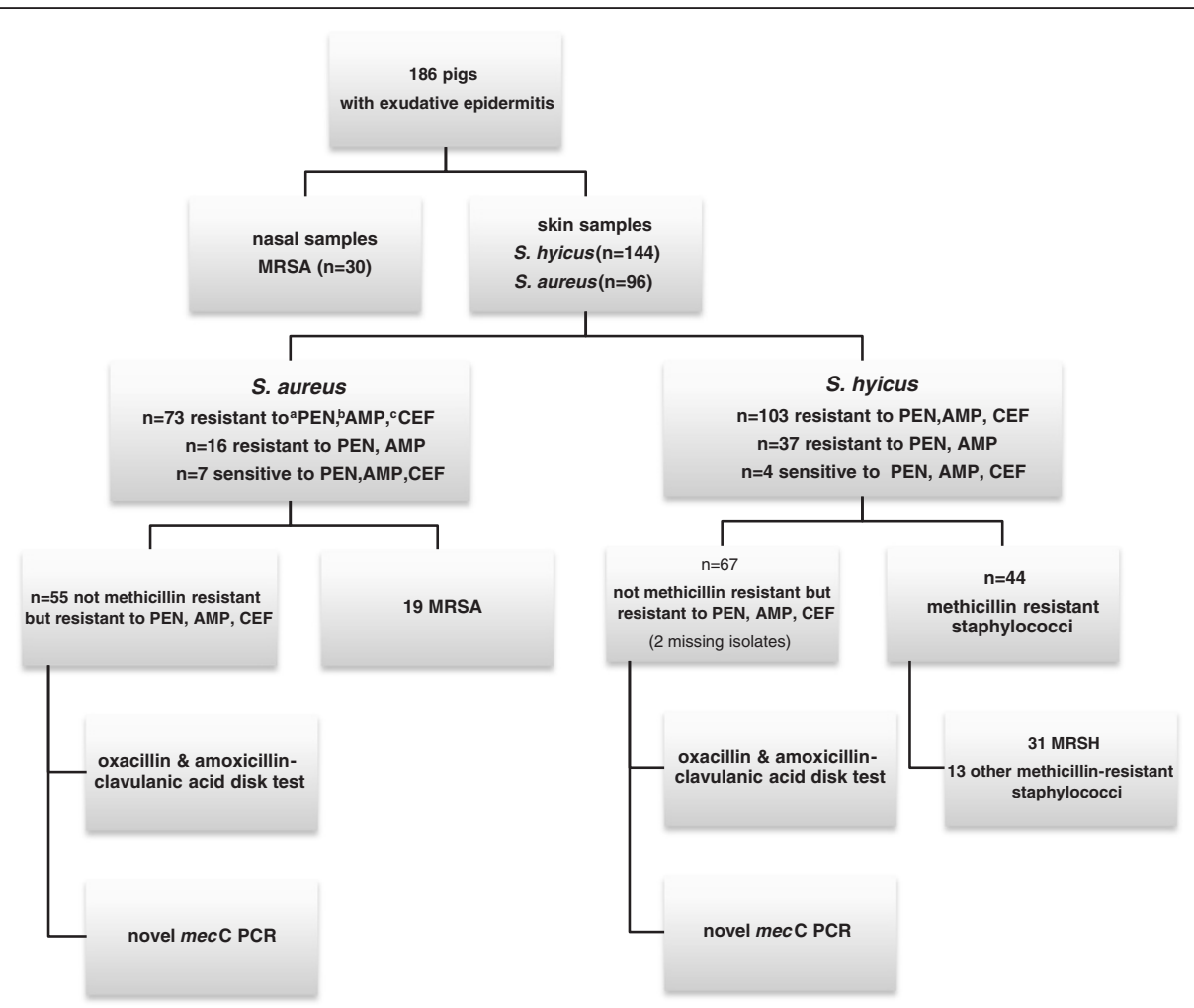

Figure 1 A flowchart of the steps taken to examine the staphylococci isolates from pigs. ${ }^{a} P E N$ : penicillin $\mathrm{G}^{\mathrm{b}} \mathrm{AMP}$ : ampicillin ${ }^{\mathrm{C} C E F}$ : ceftiofur. 
Table 1 Antimicrobial resistant characterization of methicillin-resistant staphylococci isolated from pigs with exudative epidermitis

\begin{tabular}{|c|c|c|c|c|c|c|c|}
\hline \multirow[t]{2}{*}{ Farms } & \multirow[t]{2}{*}{ Pigs } & \multirow[t]{2}{*}{ Species } & \multirow[t]{2}{*}{ Spa types } & \multirow[t]{2}{*}{ SCCmec type } & \multicolumn{3}{|c|}{ Disk diffusion susceptibility test } \\
\hline & & & & & Penicillin G & Ampicillin & Ceftiofur \\
\hline \multirow[t]{7}{*}{1} & 1 & $\operatorname{MRSA}(\mathrm{N})^{a}$ & t034(539) & SCCmec typeV & NA & NA & NA \\
\hline & 2 & $\mathrm{MRSH}^{\mathrm{c}}$ & NA & mec class $C$ & $R^{h}$ & $\mathrm{R}$ & $\mathrm{R}$ \\
\hline & & $\operatorname{MRSA}(S)^{b}$ & t034(539) & sccmec typeV & $\mathrm{R}$ & $\mathrm{R}$ & $\mathrm{R}$ \\
\hline & & MRSA(S) & t034(539) & sccmec typeV & $\mathrm{R}$ & $\mathrm{R}$ & R \\
\hline & 3 & MRSA(N) & t034(539) & SCCmec typeV & NA & NA & NA \\
\hline & & $\mathrm{MRSC}^{\mathrm{d}}$ & NA & ccr type 5 & $\mathrm{R}$ & $\mathrm{R}$ & R \\
\hline & 4 & MRSA(N) & t034(539) & SCCmec typeV & NA & NA & NA \\
\hline \multirow[t]{2}{*}{2} & 1 & MRSH & NA & SCCmec typeV & $\mathrm{R}$ & $\mathrm{R}$ & $S^{i}$ \\
\hline & 2 & MRSH & NA & SCCmec typeV & R & $\mathrm{R}$ & $R$ \\
\hline \multirow[t]{2}{*}{3} & 1 & MRSH & NA & SCCmec typeV & R & $\mathrm{R}$ & $\mathrm{R}$ \\
\hline & 2 & MRSH & NA & SCCmec typeV & R & $\mathrm{R}$ & R \\
\hline \multirow[t]{18}{*}{4} & 1 & MRSA(N) & t034(539) & SCCmec typeV & NA & NA & NA \\
\hline & & MRSA(S) & t034(539) & SCCmec typeV & $\mathrm{R}$ & $\mathrm{R}$ & $R$ \\
\hline & & MRSA(S) & t034(539) & SCCmec typeV & $\mathrm{R}$ & $\mathrm{R}$ & $\mathrm{R}$ \\
\hline & 2 & MRSA(N) & t034(539) & sccmec typeV & NA & NA & NA \\
\hline & & MRSA(S) & t034(539) & sccmec typeV & $\mathrm{R}$ & $\mathrm{R}$ & R \\
\hline & & MRSA(S) & t034(539) & SCCmec typeV & $\mathrm{R}$ & $\mathrm{R}$ & R \\
\hline & & $\mathrm{MRSAr}^{\mathrm{e}}$ & NA & sccmec typeV & $\mathrm{R}$ & $\mathrm{R}$ & R \\
\hline & 3 & MRSA(N) & t034(539) & sccmec typeV & NA & NA & NA \\
\hline & & MRSA(S) & t034(539) & SCCmec typeV & $\mathrm{R}$ & $\mathrm{R}$ & R \\
\hline & & MRSA(S) & t034(539) & sccmec typeV & $\mathrm{R}$ & $\mathrm{R}$ & R \\
\hline & 4 & MRSA(N) & t026 (93) & SCCmec typeV & NA & NA & NA \\
\hline & & MRSA(S) & t034(539) & sccmec typeV & R & $\mathrm{R}$ & R \\
\hline & & $\mathrm{MRSCO}^{f}$ & NA & SCCmec typeV & $\mathrm{R}$ & $\mathrm{R}$ & R \\
\hline & 5 & MRSA(N) & t034(539) & sccmec typeV & NA & NA & NA \\
\hline & & MRSA(S) & t034(539) & scCmec typeV & $\mathrm{R}$ & $\mathrm{R}$ & $R$ \\
\hline & 6 & MRSA(N) & t034(539) & SCCmec typeV & NA & NA & NA \\
\hline & & MRSA(S) & t034(539) & sccmec typeV & R & $\mathrm{R}$ & R \\
\hline & & MRSA(S) & t034(539) & SCCmec typeV & R & $\mathrm{R}$ & R \\
\hline 5 & 1 & MRSH & NA & ccr type 5 & $\mathrm{R}$ & $\mathrm{R}$ & $\mathrm{R}$ \\
\hline \multirow[t]{2}{*}{6} & 1 & MRSH & NA & sccmec typeV & $\mathrm{R}$ & $\mathrm{R}$ & R \\
\hline & 2 & MRSH & NA & untypeable & $\mathrm{R}$ & $\mathrm{R}$ & $\mathrm{R}$ \\
\hline \multirow[t]{7}{*}{7} & 1 & MRSH & NA & mec class A & R & $\mathrm{R}$ & R \\
\hline & 2 & MRSH & NA & mec class A & R & $\mathrm{R}$ & $\mathrm{R}$ \\
\hline & 3 & MRSH & NA & mec class A & $\mathrm{R}$ & $\mathrm{R}$ & $\mathrm{R}$ \\
\hline & & MRSH & NA & untypeable & R & $\mathrm{R}$ & $\mathrm{R}$ \\
\hline & 4 & MRSH & NA & mec class A & R & $\mathrm{R}$ & $\mathrm{R}$ \\
\hline & & MRSH & NA & untypeable & $\mathrm{R}$ & $\mathrm{R}$ & $\mathrm{R}$ \\
\hline & 5 & MRSH & NA & mec class $C$ & $\mathrm{R}$ & $\mathrm{R}$ & $\mathrm{R}$ \\
\hline 8 & 1 & MRSH & NA & sccmec typeV & $\mathrm{R}$ & $\mathrm{R}$ & S \\
\hline \multirow[t]{2}{*}{9} & 1 & MRSH & NA & sccmec typeV & R & $\mathrm{R}$ & R \\
\hline & 2 & MRSH & NA & ccr type 5 & $\mathrm{R}$ & $\mathrm{R}$ & $\mathrm{R}$ \\
\hline
\end{tabular}


Table 1 Antimicrobial resistant characterization of methicillin-resistant staphylococci isolated from pigs with exudative epidermitis (Continued)

\begin{tabular}{|c|c|c|c|c|c|c|c|}
\hline \multirow[t]{2}{*}{10} & 1 & MRSA(N) & t034(539) & SCCmec typeV & NA & NA & NA \\
\hline & 2 & MRSH & NA & SCCmec typeV & $\mathrm{R}$ & $\mathrm{R}$ & $R$ \\
\hline \multirow[t]{4}{*}{11} & 1 & MRSA(N) & t8588 & sccmec typeV & NA & NA & NA \\
\hline & 2 & $\operatorname{MRSA}(\mathrm{N})$ & t034(539) & SCCmec typeV & NA & NA & NA \\
\hline & 3 & MRSA(N) & t034(539) & sccmec typev & NA & NA & NA \\
\hline & 4 & MRSA(N) & t011 & SCCmec typeV & NA & NA & NA \\
\hline \multirow[t]{2}{*}{12} & 1 & MRSH & NA & SCCmec typeV & $\mathrm{R}$ & $\mathrm{R}$ & $\mathrm{R}$ \\
\hline & 2 & MRSPg & NA & sccmec typeV & R & $\mathrm{R}$ & $\mathrm{R}$ \\
\hline \multirow[t]{6}{*}{13} & 1 & MRSA(S) & t034(539) & SCCmec typeV & R & $\mathrm{R}$ & $R$ \\
\hline & 2 & MRSP & NA & ccr type 5 & $\mathrm{R}$ & $\mathrm{R}$ & $\mathrm{R}$ \\
\hline & & MRSC & NA & ccr type 5 & $\mathrm{R}$ & $\mathrm{R}$ & $\mathrm{R}$ \\
\hline & 3 & MRSC & NA & scCmec typelll & $\mathrm{R}$ & $\mathrm{R}$ & $\mathrm{R}$ \\
\hline & 4 & MRSC & NA & ccr type 5 & $\mathrm{R}$ & $\mathrm{R}$ & $\mathrm{R}$ \\
\hline & & MRSH & NA & ccr type 5 & $\mathrm{R}$ & $\mathrm{R}$ & $R$ \\
\hline 14 & 1 & MRSH & NA & sccmec typeV & $\mathrm{R}$ & $\mathrm{R}$ & $\mathrm{R}$ \\
\hline \multirow[t]{2}{*}{15} & 1 & MRSA(N) & t002(2) & sccmec typell & NA & NA & NA \\
\hline & 2 & MRSC & NA & sccmec typeV & $\mathrm{R}$ & $\mathrm{R}$ & $R$ \\
\hline 16 & 1 & MRSA(S) & t034(539) & sccmec typeV & S & S & S \\
\hline \multirow[t]{3}{*}{17} & 1 & MRSH & NA & SCCmec typeV & $\mathrm{R}$ & $\mathrm{R}$ & S \\
\hline & 2 & MRSH & NA & sccmec typeV & $\mathrm{R}$ & $\mathrm{R}$ & S \\
\hline & 3 & MRSH & NA & SCCmec typeV & R & $\mathrm{R}$ & $\mathrm{R}$ \\
\hline \multirow[t]{11}{*}{18} & 1 & $\operatorname{MRSA}(\mathrm{N})$ & t034(539) & sccmec typeV & NA & NA & NA \\
\hline & 2 & $\operatorname{MRSA}(\mathrm{N})$ & t034(539) & sccmec typeV & NA & NA & NA \\
\hline & & MRSA(S) & NA & scCmec typeV & $\mathrm{R}$ & $\mathrm{R}$ & $\mathrm{R}$ \\
\hline & 3 & MRSA(N) & t034(539) & sccmec typeV & NA & NA & NA \\
\hline & & MRSA(S) & NA & SCCmec typeV & $\mathrm{R}$ & $\mathrm{R}$ & $\mathrm{R}$ \\
\hline & 4 & MRSA(N) & t034(539) & SCCmec typeV & NA & NA & NA \\
\hline & & MRSA(S) & NA & sccmec typeV & $\mathrm{R}$ & $\mathrm{R}$ & R \\
\hline & & MRSH & NA & SCCmec typeV & $\mathrm{R}$ & $\mathrm{R}$ & $\mathrm{R}$ \\
\hline & 5 & $\operatorname{MRSA}(\mathrm{N})$ & t034(539) & sccmec typeV & NA & NA & NA \\
\hline & & MRSA(S) & NA & SCCmec typeV & $\mathrm{R}$ & $\mathrm{R}$ & $\mathrm{R}$ \\
\hline & 6 & $\operatorname{MRSA}(\mathrm{N})$ & t034(539) & sccmec typeV & NA & NA & NA \\
\hline \multirow[t]{11}{*}{19} & 1 & MRSA(N) & t034(539) & sccmec typeV & NA & NA & NA \\
\hline & & MRSC & NA & scCmec typeV & $\mathrm{R}$ & $\mathrm{R}$ & $\mathrm{R}$ \\
\hline & & MRSC & NA & sccmec typeV & $\mathrm{R}$ & $\mathrm{R}$ & $\mathrm{R}$ \\
\hline & 2 & MRSA(N) & t034(539) & SCCmec typeV & NA & NA & NA \\
\hline & & MRSC & NA & sccmec typeV & $\mathrm{R}$ & $\mathrm{R}$ & $\mathrm{R}$ \\
\hline & & MRSC & NA & ccr type 5 & $\mathrm{R}$ & $\mathrm{R}$ & $\mathrm{R}$ \\
\hline & 3 & MRSA(N) & t034(539) & SCCmec typeV & NA & NA & NA \\
\hline & 4 & MRSA(N) & t034(539) & scCmec typeV & NA & NA & NA \\
\hline & 5 & $\operatorname{MRSA}(\mathrm{N})$ & $\mathrm{t} 1298$ & scCmec typeV & NA & NA & NA \\
\hline & 6 & MRSA(N) & t034(539) & sccmec typeV & NA & NA & NA \\
\hline & & MRSA(S) & t571(109) & SCCmec typeV & $\mathrm{R}$ & $\mathrm{R}$ & S \\
\hline 20 & 1 & MRSA(N) & t034(539) & SCCmec typeV & NA & NA & NA \\
\hline
\end{tabular}


Table 1 Antimicrobial resistant characterization of methicillin-resistant staphylococci isolated from pigs with exudative epidermitis (Continued)

\begin{tabular}{|c|c|c|c|c|c|c|}
\hline \multirow[t]{2}{*}{2} & MRSA(N) & t034(539) & scCmec typeV & NA & NA & NA \\
\hline & MRSH & NA & SCCmec typeV & $\mathrm{R}$ & $\mathrm{R}$ & S \\
\hline \multirow[t]{2}{*}{3} & MRSH & NA & SCCmec typeV & $\mathrm{R}$ & $\mathrm{R}$ & $S$ \\
\hline & MRSH & NA & sccmec typeV & $\mathrm{R}$ & $\mathrm{R}$ & $\mathrm{R}$ \\
\hline 4 & $\operatorname{MRSA}(\mathrm{N})$ & t034(539) & sccmec typeV & NA & NA & NA \\
\hline 5 & MRSH & NA & SCCmec typeV & $\mathrm{R}$ & $R$ & S \\
\hline 6 & $\mathrm{MRSH}$ & NA & SCCmec typeV & $\mathrm{R}$ & $\mathrm{R}$ & $S$ \\
\hline
\end{tabular}

${ }^{a}$ MRSA(N): methicillin-resistant Staphylococcus aureus recovered from nasal swabs.

${ }^{\mathrm{b}} \mathrm{MRSA}(\mathrm{S})$ : methicillin-resistant Staphylococcus aureus recovered from skin swabs.

'MRSH: methicillin-resistant Staphylococcus hyicus recovered from skin swabs.

${ }^{d}$ MRSC: methicillin-resistant Staphylococcus chromogenes recoverd from skin sw.abs

${ }^{e}$ MRSAr: methicillin-resistant Staphylococcus arlettae recovered from skin swabs.

fMRSCo: methicillin-resistant Staphylococcus cohnii recovered from skin swabs.

${ }^{9}$ MRSP: methicillin-resistant Staphylococcus pseudintermidius recovered from skin swabs.

${ }_{\mathrm{h}} \mathrm{R}$ : resistant.

'S: susceptible.

NA: not applicable.

class A or class $\mathrm{C}$, or $\mathrm{ccr}$ gene complex type 5. Three MRSH had any neither mec gene complex nor ccr gene complex, and so SCCmec typing was repeated for these non- typeable isolates. Multiple isolates with the same incomplete SCCmec typing results were found on 2 farms. While 2 different staphylococcal species possessing the same complete SCCmec type were found on 5 farms. Three pigs were found to harbour both MRSH and MRSA (nasal samples) in the same SCCmec type V. One pig had harboured both MRSH and MRSA (skin), both of which harboured mec gene complex class $\mathrm{C}$. Four other pigs harboured both MRSA and other methicillin-resistant staphylococci (other than MRSH), and they possessed SCCmec typeV or ccr gene complex type 5 .

Sixty-seven isolates of $S$. hyicus were mecA negative but resistant to $3 \beta$-lactam antimicrobials (penicillin G, ampicillin and ceftiofur). Sixty-two (92.5\%) were susceptible to both oxacillin and amoxicillin-clavulanic acid, while $3(4.5 \%)$ were resistant to oxacillin but susceptible to amoxicillin-clavulanic acid and $2(3.0 \%)$ were susceptible to oxacillin but resistant to amoxicillin-clavulanic acid. Further, the 3 oxacillin-resistant, amoxicillin-clavulanic acid susceptible isolates did not show an alteration of the zone of inhibition in the double disk test. These 67 S. hyicus isolates tested negative for mecC.

Fifty-five isolates of $S$. aureus were mecA negative but resistant to the penicillin G, ampicillin and ceftiofur. Twentysix $(47.3 \%)$ of these were susceptible to both oxacillin and amoxicillin-clavulanic acid and 8 (14.5\%) isolates were resistant to oxacillin but susceptible to amoxicillin-clavulanic. Twenty-one isolates (38.2\%) were resistant to both oxacillin and amoxicillin-clavulanic acid but, when the double disk test was used, alteration of the zone of inhibition was apparent for 20 (95.2\%) isolates; suggesting oxacillin resistance was mediated through excessive $\beta$-lactamase production. These 55 S. aureus isolates were $m e c C$ negative.

\section{Discussion}

There has been considerable work done to examine the prevalence of MRSA in the pig population [6-9] and its

Table 2 Overview of SCCmec elements found 93 methicillin-resistant staphylococci isolated from pigs with exudative epidermitis

\begin{tabular}{lllll}
\hline ccr-complex & mec-complex & SCCmec type & n. isolates & Species (n. isolates) \\
\hline ccr type 2 & class A & II & 1 & S. aureus (1) \\
ccr type 3 & class A & III & S. chromogenes (1) \\
ccr type 5 & class C & $V$ & 74 & S. hyicus (19), S. aureus (48), S. chromogenes (4), \\
Ccr type 5 & NF & NT type3 & & S. pseudintermedius (1), S. arlettae (1), S. cohnii subsp. Urealyticus (1) \\
$N F^{\text {a }}$ & class A & NT type2 & 4 & S. hyicus (3), S. chromogenes (4), S. pseudintermedius (1) \\
$N F$ & class C & NT type 1 & 2 & S. hyicus (4) \\
$N F$ & NF & NT type 4 & 3 & S. hyicus (2) \\
\hline
\end{tabular}

${ }^{\mathrm{a} N F}$ : non finder.

${ }^{\mathrm{b}} \mathrm{NT}$ : non-typeable cassette; the categorization into 'type 1,2,3, and 4' was done on the moment of detection. 
association with human infection because of the potential public health risk [21]. MRSA is presumed to have acquired $m e c A$ from coagulase negative staphylococci [22], and methicillin-resistant coagulase negative staphylococci are common commensals [14,22]. Methicillin-resistance has emerged, presumably in a similar manner, in other pathogenic staphylococci. Therefore, it is reasonable to consider that transmission of mecA between S. aureus and S. hyicus, in either direction, might occur on pig farms where both staphylococcal species are present, particularly in the presence of regular therapeutic or prophylactic use of $\beta$-lactam antimicrobials.

The finding of mecA in S. hyicus is important for a number of reasons. From a swine health standpoint, it is of relevance because of resistance to penicillin and ceftiofur, two commonly used antimicrobials [23]. From a public health standpoint the finding that MRSA and MRSH can carry the same SCCmec raises the concern that the genetic material conferring multiple antimicrobial resistance may be passing from species to species within the bacterial population of a farm, and raises questions about whether MRSH could ultimately be a source for further emergence of MRSA clones on pig farms. Finding the same SCCmec does not indicate whether mecA was transmitted from S. aureus to S. hyicus, from S. hyicus to $S$. aureus or to both S. hyicus and S. aureus from another source. Further study of transmission of $m e c A$ between different staphylococci at the pig or farm level is warranted. Thus, while S. hyicus is of little zoonotic relevance, the public health relevance of MRSH cannot be completely dismissed.

SCCmec type was not determined for $38.7 \%$ of MRSH, $44.4 \%$ of MRSC, and $50 \%$ of MRSP because the primers that were used were unable to detect either the mec or ccr complexes $(\mathrm{n}=3)$, only detecting the mec complex $(\mathrm{n}=6)$ or only detecting the $c c r$ complex $(\mathrm{n}=8)$. This is not unexpected since there has been limited investigation other than in MRSA. SCCmec types other than those evaluated here are described and it is possible that further testing would have clarified the SCCmec type in the isolates in the present study. However, even with testing for all described SCCmec types, some isolates may remain untypable [24] and it was determined that additional typing would have contributed little to fulfilling the main objectives of this study.

One curious finding here was the presence of isolates that were resistant to $\beta$-lactams and $\beta$-lactam $/ \beta$-lactam inhibitor combinations but mecA negative. To the authors' knowledge, the only known mechanism for ceftiofur and amoxicillin-clavulanic acid resistance in staphylococci is methicillin resistance, and this suggests that a different mec element that is not detectable by conventional mecA PCR or PBP2a LAT could be involved. One recent example of this is $m e c C$ (previously referred to as $m e c A_{\mathrm{LGA} 251}$ ) which has been identified in animals and humans in Europe $[16,20,25]$. However, this mecC gene was not detected. This does not exclude the possibility that a different novel mec element was present. It is noteworthy that double disk diffusion testing indicated an impact of clavulanic acid on oxacillin resistance, suggesting that hyperproduction of $\beta$-lactamase might be the cause of the resistance for some $(\mathrm{n}=20)$ mecA negative $\beta$-lactam resistant $S$. aureus isolates.

\section{Conclusions}

Methicillin resistance can be identified in a variety of staphylococcal species isolated from pigs. In this study there was a great deal of similarity in the SCCmec types between staphylococcal species, suggesting that resistance may be passed from one species of staphylococci to another species of staphylococci. While this has been reported for acquisition of methicillin-resistant from coagulase negative staphylococci to $S$. aureus, these data suggest that transmission to or from the porcine pathogen $S$. hyicus may also occur. The identification of methicillin resistance in a variety of staphylococcal species in pigs does raise concerns about the spread of serious multi-drug resistance in food producing animals and warrants further study.

\section{Competing interests}

The authors acknowledge no conflict of interest.

\section{Authors' contributions}

All authors contributed to the writing of the paper. JP was primarily responsible for collecting the samples and performing the laboratory tests. All authors read and approved the manuscript.

\section{Acknowledgments}

This work was partially financed by Ontario Pork, Ontario Ministry of Agriculture Food and Rural Affairs and NSERC. We gratefully acknowledge the pork producers who participated and the contributions of the Animal Health Laboratory, University of Guelph for the initial culture of isolates. We also appreciate the technical assistance of Joyce Rousseau who helped with the molecular laboratory work.

\section{Author details}

${ }^{1}$ Department of Population Medicine, Ontario Veterinary College, University of Guelph, 50 Stone Road, Guelph N1G2W1, ON, Canada. 'Department of Pathobiology, Ontario Veterinary College, University of Guelph, 50 Stone Road, Guelph N1G 2W1, ON, Canada.

Received: 30 January 2013 Accepted: 11 October 2013

Published: 17 October 2013

\section{References}

1. Wegener HC, Skov-Jensen EW: Exudative epidermitis. In Diseases of Swine. 9th edition. Edited by Straw BE, Zimmerman JJ, D'Allaire S, Taylor DJ. Ames, lowa: Blackwell Pub; 2006:675-679.

2. Aarestrup FM, Jensen LB: Trends in antimicrobial susceptibility in relation to antimicrobial usage and presence of resistance genes in Staphylococcus hyicus isolated from exudative epidermitis in pigs. Vet Microbiol 2002, 89(1):83-94.

3. Aarestrup FM, Oliver Duran C, Burch DG: Antimicrobial resistance in swine production. Anim Health Res Rev 2008, 9(2):135-148.

4. Werckenthin C, Cardoso M, Martel JL, Schwarz S: Antimicrobial resistance in staphylococci from animals with particular reference to bovine Staphylococcus aureus, porcine Staphylococcus hyicus, and canine Staphylococcus intermedius. Vet Res 2001, 32(3-4):341-362. 
5. Park J, Friendship RM, Poljak Z, Weese JS, Dewey CE: An investigation of exudative epidermitis (greasy pig disease) and antimicrobial resistance patterns of Staphylococcus hyicus and Staphylococcus aureus isolated from clinical cases. Can Vet J 2013, 54:139-144.

6. Anon: Analysis of the baseline survey on the prevalence of methicillinresistant Staphylococcus aureus (MRSA) in holdings with breeding pigs, in the EU, 2008 [1] - Part A: MRSA prevalence estimates. EFSA J 2009, 7(11):1376.

7. Sergio DM, Koh TH, Hsu LY, Ogden BE, Goh AL, Chow PK: Investigation of meticillin-resistant Staphylococcus aureus in pigs used for research. J Med Microbiol 2007, 56(Pt 8):1107-1109.

8. Smith TC, Male MJ, Harper AL, Kroeger JS, Tinkler GP, Moritz ED, Capuano AW, Herwaldt LA, Diekema DJ: Methicillin-resistant Staphylococcus aureus (MRSA) strain ST398 is present in midwestern U.S. swine and swine workers. Plos One 2009, 4(1):e4258.

9. Khanna T, Friendship R, Dewey C, Weese JS: Methicillin resistant Staphylococcus aureus colonization in pigs and pig farmers. Vet Microbiol 2008, 128(3-4):298-303.

10. Taylor DJ, Taylor DJ: Miscellaneous Bacterial Infections. In Diseases of Swine. 9th edition. Edited by Straw BE, Zimmerman JJ, D'Allaire S, Taylor DJ. Ames, lowa: Blackwell Pub; 2006:817-846.

11. Cameron R: Diseases of the skin. In Diseases of Swine. 9th edition. Edited by Straw BE, Zimmerman JJ, D'Allaire S, Taylor DJ. Ames, lowa: Blackwell Pub; 2006:179-198

12. Paterson DL, Bonomo RA: Extended-spectrum beta-lactamases: a clinical update. Clin Microbiol Rev 2005, 18(4):657-686.

13. Clinical and Laboratory Standards Institute: Performance Standards for Antimicrobial Disk and Dilution Susceptibility Tests for Bacteria Isolated from Animals; Approved Standard-Third Edition. CLSI document 2008, 28(8):M31-A3.

14. Sasaki T, Tsubakishita S, Tanaka Y, Sakusabe A, Ohtsuka M, Hirotaki S, Kawakami T, Fukata T, Hiramatsu K: Multiplex-PCR method for species identification of coagulase-positive staphylococci. J Clin Microbiol 2010, 48(3):765-769

15. Wielders CL, Fluit AC, Brisse S, Verhoef J, Schmitz FJ: mecA gene is widely disseminated in Staphylococcus aureus population. J Clin Microbiol 2002, 40(11):3970-3975.

16. Stegger M, Andersen PS, Kearns A, Pichon B, Holmes MA, Edwards G, Laurent F, Teale C, Skov R, Larsen AR: Rapid detection, differentiation and typing of methicillin-resistant Staphylococcus aureus harbouring either mecA or the new mecA homologue mecA(LGA251). Clin Microbiol Infect 2012, 18:395-400

17. Shopsin B, Gomez M, Montgomery SO, Smith DH, Waddington M, Dodge DE, Bost DA, Riehman M, Naidich S, Kreiswirth BN: Evaluation of protein A gene polymorphic region DNA sequencing for typing of Staphylococcus aureus strains. J Clin Microbiol 1999, 37(11):3556-3563.

18. Zhang K, McClure JA, Elsayed S, Louie T, Conly JM: Novel multiplex PCR assay for characterization and concomitant subtyping of staphylococcal cassette chromosome mec types I to $\mathrm{V}$ in methicillin-resistant Staphylococcus aureus. J Clin Microbiol 2005, 43(10):5026-5033.

19. Kondo Y, Ito T, Ma XX, Watanabe S, Kreiswirth BN, Etienne J, Hiramatsu K Combination of multiplex PCRs for staphylococcal cassette chromosome mec type assignment: rapid identification system for $m e c, c c r$, and major differences in junkyard regions. Antimicrob Agents Chemother 2007, 51(1):264-274

20. Garcia-Alvarez L, Holden MTG, Lindsay H, Webb CR, Brown DF, Curran MD, Walpole E, Brooks K, Pickard DJ, Teale C, Parkhill J, Bentley SD, Edwards GF, Girvan EK, Kearns AM, Pichon B, Hill RLR, Larsen AR, Skov RL, Peacock SJ, Holmes MA: Meticillin-resistant Staphylococcus aureus with a novel mecA homologue in human and bovine populations in the UK and Denmark: a descriptive study. Lancet Infect Dis 2011, 11:595-603.

21. Voss A: Methicillin-resistant Staphylococcus aureus in pig farming. Emerging infectious diseases 2005, 11(12):1965-1966.

22. Tsubakishita S, Kuwahara-Arai K, Sasaki T, Hiramatsu K: Origin and molecular evolution of the determinant of methicillin resistance in staphylococci. Antimicrob Agents Chemother 2010, 54(10):4352-4359.

23. Friendship RM, Prescott JF: Drug Therapy and Prophylaxis. In Diseases of Swine. 9th edition. Edited by Straw BE, Zimmerman JJ, D'Allaire S, Taylor DJ. Ames, lowa: Blackwell Pub; 2006:1131-1143.
24. Vanderhaeghen W, Vandendriessche S, Crombe F, Dispas M, Denis O, Hermans K, Haesebrouck F, Butaye P: Species and staphylococcal cassette chromosome mec (SCCmec) diversity among methicillin-resistant non-Staphylococcus aureus staphylococci isolated from pigs. Vet Microbiol 2012, 158(1-2):123-128.

25. Fluit AC: What to do with MRSA with a novel mec gene? Lancet Infect Dis 2011, 11(8):580-581.

doi:10.1186/1746-6148-9-211

Cite this article as: Park et al:: An investigation of resistance to $\beta$-lactam antimicrobials among staphylococci isolated

from pigs with exudative epidermitis. BMC Veterinary Research 2013 9:211.

\section{Submit your next manuscript to BioMed Central and take full advantage of:}

- Convenient online submission

- Thorough peer review

- No space constraints or color figure charges

- Immediate publication on acceptance

- Inclusion in PubMed, CAS, Scopus and Google Scholar

- Research which is freely available for redistribution

Submit your manuscript at www.biomedcentral.com/submit
C BioMed Central 